\title{
High Fluence Low Intensity Laser Irradiation Bioinhibits Viability and Proliferation of Lung Cancer Stem Cells
}

\section{Anine Crous and Heidi Abrahamse*}

Laser Research Centre, Faculty of Health Sciences, University of Johannesburg, South Africa

\begin{abstract}
Lung cancer contributes to high cancer mortality rates worldwide. Contributing factors are metastatic potential and Cancer Stem Cells (CSCs). CSCs have been described as stem-like cells with cancer characteristics that include: self-renewal, exponential proliferation, cell differentiation and metastasis. Photobiomodulation have been used in different therapeutic models by treating disease using Low Intensity Laser Irradiation (LILI). Studies have shown that LILI can cause photo-stimulation or inhibition on various cell lines depending on the intensity used. Various studies have been conducted on CSCs. In this study we analysed the possible stimulatory and inhibitory outcomes LILI have on isolated CD133+ lung CSCs. The cells received irradiation at a wavelength of 636, 825 and $1060 \mathrm{~nm}$. All wavelengths were used at treatment fluences of $5,10,20$ and $40 \mathrm{~J} / \mathrm{cm}^{2}$. The various cellular responses were then examined over a time period of 24,48 or $72 \mathrm{~h}$. Treatment responses were evaluated using biochemical assays for cell viability, proliferation and cytotoxicity. Results revealed CSCs are stimulated when irradiated at wavelengths of 636 $\mathrm{nm}$ and $825 \mathrm{~nm}$ with fluences ranging between $5 \mathrm{~J} / \mathrm{cm}^{2}$ and $20 \mathrm{~J} / \mathrm{cm}^{2}$ and that the CSCs are inhibited using a higher fluence of $40 \mathrm{~J} / \mathrm{cm}^{2}$.
\end{abstract}

Keywords: Cancer stem cells; Low intensity laser irradiation; Proliferation; Cytotoxicity

Abbreviations: CSCs: Cancer Stem Cells; LILI: Low Intensity Laser Irradiation; SC: Stem Cell; HH: Hedgehog; LF: Low Fluences; HF-LILI: High Fluence LILI; ROS: Reactive Oxygen Species

\section{Introduction}

Cancer is the pathological disease state of a cell caused by genetic mutations allowing for characteristics such as irrepressible cell proliferation along with self-renewal, self-sustainability and evasion of normal cell cycle processes like cell death leading to tumour formation [1,2]. Lung cancer has been ascribed the title for leading cancer mortality rates globally [3]. Research attributed to lung cancer has been going on for the past decade in order to better understand its mechanism and to advance treatment and diagnosis [4]. Despite these advancements it still has an aggressive approach to treatments characterised by drug-resistance and the capability to metastasise [5]. Thus, remaining a primary threat contributing to the growing number of cancer mortality rates and relapse.

Metastasis, one of the contributing factors to poor prognosis of lung cancer has been ascribed to a specialised subset of cells possessing cancer properties [6]. The hypothesis supporting the above mentioned statement is the Cancer Stem Cell (CSC) hypothesis which describes cancer initiation and maintenance. The hypothesis states that an intermittent population of cancerous cells, having stem cell (SC) like characteristics, is responsible for tumour growth, resistance, and recurrence [7]. The term tumour-initiating cells are sometimes preferred, also referring to CSCs due to their tumour initiating capabilities and asymmetric cell division. The characteristics these cells portray are similar to those of SCs because of their ability to selfrenew, differentiate into specialised cells and most importantly migrate $[8,9]$. Along with normal SC characteristics the tumorigenic properties the cells display include multidrug resistance, the expression of antiapoptotic proteins, drug efflux pumps and tumour regeneration after treatment [10]. In SCs there are molecular pathways that maintain 'stemness' that are also found to be active in different cancers [2]. Proposing that mutations of these molecular pathways can cause abnormal cell growth. SCs quiescently reside in a SC-niche maintaining the cells. In CSCs this niche called the CSCs niche may promote enhanced DNA repair. The quiescent phenotype, as well as the high rate of DNA repair may contribute to their therapeutic resistance [11]. Research has proven the existence of these cells and have been found in various cancers [12]. Lung cancer patients have been shown to present with early disseminated disease irrespective of the size of the tumour. This would suggest that these tumours are enriched for CSCs [13]. Normal pulmonary precursor behaviour is guided by the Notch, Hedgehog $(\mathrm{HH})$, and Wnt pathways also defining normal SCs. Irregular pathway signalling can lead to undesired expansion of pulmonary SCs which can develop into CSC lineages ultimately leading to lung cancer and tumour formation [14]. In addition to the genes involved in the Notch, Wnt, and $\mathrm{HH}$ pathways, there are numerous genetic markers associated with CSCs. CSCs have been identified and were isolated from different cancers including lung cancer. This was achieved by using antigenic markers displayed by normal SCs indicating their stem-ness [15]. A popular lung CSC marker which has been used to isolate the subpopulation of cells is CD133. The cells displayed properties that included the increased capability to self-renew, drug resistance and high tumorigenic potential as well as increased expression of stem-ness [16-18]. CD133, also known as Prominin-1, is a member of the pentaspan transmembrane (5-TM) glycoprotein family. In humans, the Prominin-1 gene is located on chromosome 4 p15 and encodes a $120-\mathrm{kD}$ transmembrane glycoprotein [19], which localizes to membrane protrusions.

*Corresponding author: Heidi Abrahamse, Director, Laser Research Centre, Faculty of Health Sciences, University of Johannesburg, PO Box 17011 Johannesburg 2028, South Africa, Tel: +27 115596550; Fax: +27115596884; Email: habrahamse@uj.ac.za

Received November 29, 2016; Accepted December 12, 2016; Published December 19, 2016

Citation: Crous A, Abrahamse H (2016) High Fluence Low Intensity Laser Irradiation Bioinhibits Viability and Proliferation of Lung Cancer Stem Cells. J Stem Cell Res Ther 6: 368. doi: 10.4172/2157-7633.1000368

Copyright: ( $) 2016$ Crous A, et al. This is an open-access article distributed unde the terms of the Creative Commons Attribution License, which permits unrestricted use, distribution, and reproduction in any medium, provided the original author and source are credited. 
Photobiomodulation operates by way of photochemistry relying on specific factors such as wavelength, fluence, power density, pulse structure and treatment time when applied in biological tissue. Specific light-absorbing molecules can then be targeted. The light energy absorbed produces singlet oxygen or superoxide via singlet state excitation of oxygen molecules or electron reduction respectively. Similar to normal cells cancer cells also comprise of intracellular chromophores. Different cellular chromophores are stimulated at different wavelengths [20]. The photobiomodulative therapy Low Intensity Laser Irradiation (LILI) uses coherent light at a specific wavelength in the visible spectrum that consists of red and nearinfrared light between 600-1070 $\mathrm{nm}$. Research shows that tissue penetration is optimal at these wavelengths. Cells or tissues that are exposed to visible red light and near-IR light have shown to either have a biostimulatory or bioinhibitory outcome [21]. The photobiological effect takes place at the mitochondrial level whereby chromophores are stimulated. Wavelength and fluence have various metabolic outcomes [22]. Biostimulatory responses showing an increase in viability and proliferation were seen in various cell lines when using LILI with wavelengths between $625-675 \mathrm{~nm}$ and Low Fluences (LF) ranging from $1 \mathrm{~J} / \mathrm{cm}^{2}$ to $15 \mathrm{~J} / \mathrm{cm}^{2}$ [23-27], however bioinhibition was achieved at longer wavelengths of $800-830 \mathrm{~nm}$ and fluence of $\geq 10 \mathrm{~J} / \mathrm{cm}^{2}[24,28,29]$. Studies have also shown that laser light have been able to cause cancer cell destruction by using high fluence LILI (HF-LILI) [30]. It has been reported by Wang et al. [31], that HF-LILI can induce apoptosis in lung cancer cells. The reason for apoptosis has been said to be due to an increase in reactive oxygen species (ROS) which is toxic to the cell, as a result of the endogenous photo acceptors in the cell being stimulated by LILI [32]. The reason behind implementation of LILI is due to evidence signifying that laser photons induce photo-bio modulation stimulating a significant amount of cellular biological effects having results where a stimuli was produced that increases cellular viability and proliferation. As well as stimuli causing a regressive response of bio modulation where there is a generation of reactive oxygen species (ROS) which are toxic to cancer cells and evidently leading to cellular death [20].

This exploratory study was aimed at investigating the possible outcomes that various laser intensities and wavelengths would have on isolated lung CSCs. Isolated lung CSCs, positive for the antigenic marker CD133, were irradiated with LF-LILI of $5-20 \mathrm{~J} / \mathrm{cm}^{2}$ and a HF-LILI of 40 $\mathrm{J} / \mathrm{cm}^{2}$. The lasers used emitted wavelengths of 636, 825 and $1060 \mathrm{~nm}$. After treatment with low and high fluence LILI biochemical assays were conducted on the treated lung CSCs and their control groups over a time period of 24, 48 and $72 \mathrm{~h}$ to determine various cellular responses. Cellular viability, proliferation, and cytotoxicity assays allowed for various LILI treatment outcomes to be evaluated.

\section{Materials and Methods}

A group of CSCs, isolated from the lung cancer cell line A549, positive for the antigenic marker CD133 received treatment using LFLILI with fluences of 5-20 J/cm ${ }^{2}$ and HF-LILI using a fluence of $40 \mathrm{~J} / \mathrm{cm}^{2}$ from lasers with wavelengths of 636, 825 and $1060 \mathrm{~nm}$ respectively. Post irradiation biochemical responses were analysed over a time period of 24,48 and $72 \mathrm{~h}$ to obtain results on the cellular reaction as time elapse.

\section{Cell culture}

Commercially available lung cancer cells received from the ATCC were used in this study (A549, ATCC CCL-185). The media used for culturing of lung cancer cells and isolated CSCs consisted of the following: Rosewell Park Memorial Institute 1640 medium (RPMI1640) (Sigma, R8758) supplemented with $10 \%$ foetal bovine serum
(FBS) (Biochrom, S0615) and 0.5\% penicillin/streptomycin (Sigma, P4333) and 0.5\% amphotericin B (Sigma, A2942). Cultured cells were incubated at $37^{\circ} \mathrm{C}$ in $5 \% \mathrm{CO}_{2}$ and $85 \%$ humidity.

Control cell line $\mathrm{CaCo}_{2}\left(\right.$ ATCC $^{\oplus}, \mathrm{HTB}^{3} 7^{\mathrm{ms}}$ ) were cultured in Dulbecco's Modified Eagle's Media (DMEM) (Sigma, D5796) supplemented with 10\% FBS (Biochrom, S0615), 2 mM L-Glutamine (Sigma, G7513), 1\% penicillin/streptomycin (Sigma, P4333) and 1\% amphotericin B (Sigma, A2942). SKUT-1 (ATCC, HTB114 ${ }^{\text {stx }}$ ) was cultured in DMEM (Sigma, D5796) supplemented with 10\% FBS (Biochrom, S0615) and 1\% penicillin/streptomycin (Sigma, P4333) and 1\% amphotericin B (Sigma, A2942).

\section{Isolation of side population cells}

The magnetic bead isolation kit and separation unit (Miltenyi Biotec, QuadroMACS ${ }^{\text {mox }}$ separation unit 130-091-051) was used to isolate lung CSCs. The cells were magnetically labelled with microbead conjugated antibodies directed at the antigenic surface marker CD133. The cell population was enriched for $\mathrm{CD} 133^{+}$lung CSCs by using the CD133 MicroBead Kit (Miltenyi Biotec, CD133 MicroBead Kit, human 130-050-801) designed for the positive selection of cells expressing the human CD133 antigen.

The cell number was determined from a single cell suspension. The cells were spun down and re-suspended in $80 \mu \mathrm{l}$ buffer and $20 \mu \mathrm{l}$ Microbeads per 107 total cells, cells were then incubated for 15 minutes at $2-80^{\circ} \mathrm{C}$. Cells were washed by using buffer solution from the kit through centrifugation at $3000 \mathrm{rpm}$ for $10 \mathrm{~min}$, then re-suspended in $500 \mu \mathrm{l}$ buffer per 107 cells, which was repeated 3 times. Separation columns were prepared by running buffer through the column and discarding the effluent. The microbead conjugated cell suspension was carefully added to the prepared separation column (Miltenyi Biotec, 130-042201), avoiding cell clumps which would cause the cells to get stuck in the column. Cells which were unlabelled would flow through the column and were collected in a collection tube and discarded. Positively selected cells would remain in the magnetic column, which would then be flushed out into a suitable collection tube using buffer and a plunger.

\section{Protein detection of CD133}

To confirm whether cells isolated using the magnetic bead kit, were of CSC origin, cells were fluorescently labelled for the antigenic marker CD133. Anti-CD133 (Prominin-1), a rabbit monoclonal antibody (Abnova, PAB12663), was used. Isolated cells along with control cell lines $\mathrm{CaCo}_{2}$ and SKUT-1 were placed in a suspension where they were washed twice with ice-cold phosphate-buffered saline (PBS)/bovine serum albumin (BSA)/azide buffer (Sigma, P4417); 0.1\% w/v BSA (Sigma, A2153); 0.01\% w/v azide (Sigma, S8032) and then incubated with $10 \%$ serum (Normal Goat Serum, abcam, ab7481) for $30 \mathrm{~min}$. on ice as a blocking step and washed twice as previously described. Cells were then incubated with $100 \mu$ primary antibody, rabbit antihuman $\mathrm{CD}_{133^{+}}$(Abnova, PAB12663), in working buffer (2\% serum in PBS BSA/azide buffer) for $30 \mathrm{~min}$, keeping the cells suspended in tubes on ice. Cells were then rinsed three times with PBS BSA/azide buffer and incubated with $100 \mu$ of the secondary fluorescent antibody, mouse anti-rabbit (abcam, ab6717) in working buffer for $30 \mathrm{~min}$ on ice, protected from light where after they were washed again with PBS BSA/Azide. The antigenic detection was done using a flow cytometer (FACSDiva Version 6.1.3 Flow Cytometer, BD Biosciences) which detects the fluorescence on the conjugated antibody, indicating if the cells are CD133 positive/negative. 


\section{LF-LILI/ HF-LILI}

Cells were irradiated from above, at room temperature with the culture dish lid off. Irradiation was performed in the dark omitting nuisance variables that would interfere with the laser effect such as polychromatic light. Cell cultures were divided into 5 study groups. Group 1 was an un-irradiated control, group 2 received irradiation at $5 \mathrm{~J} / \mathrm{cm}^{2}$, group 3 was irradiated at $10 \mathrm{~J} / \mathrm{cm}^{2}$, group 4 irradiated with a fluence of $20 \mathrm{~J} / \mathrm{cm}^{2}$ and group 5 with $40 \mathrm{~J} / \mathrm{cm}^{2}$, all with the respective wavelengths. Laser parameters are indicated in Table 1. Postirradiation, cells were incubated for 24,48 or $72 \mathrm{~h}$. Pre-irradiation cells were prepared in the following way: isolated lung CSCs were seeded at a concentration of $1 \times 10^{5}$ in $3.5 \mathrm{~cm}$ diameter treated plastic dishes.

Each petri dish containing cells received $3 \mathrm{ml}$ of complete media and incubated over night for attachment. After $24 \mathrm{~h}$ incubation at $370^{\circ} \mathrm{C}$, the monolayer was rinsed 3 times with HBSS, where after another $3 \mathrm{ml}$ of complete media was added before irradiation. In order to calculate the amount of energy the cells were going to receive, the power output of the laser was obtained using a power meter, the exposure time was calculated in order for the cells to receive energy with a fluence of 5-40 $\mathrm{J} / \mathrm{cm}^{2}$. The culture dish containing the isolated cells were then placed directly into the irradiation beam. The beam of the laser was delivered through an optical fibre of $0.5 \mathrm{~mm}$ diameter, which allows for even distribution of monochromatic light on to the cultured cells. The tip of the fibre was positioned at a suitable distance from the culture dish. During cell irradiation, illumination of the entire culture dish was achieved as the beam diameter was set at $3.5 \mathrm{~cm}$, allowing for all the cells to receive the same amount of energy from the laser.

\section{Viability}

The number of viable cells was determined using the dye exclusion test. With this assay live (viable) cells with intact membranes will exclude certain dyes such as trypan blue and remain colourless, whereas dead (non-viable) cells will retain the dye and stain blue. Ten microliters of cell suspension was added to $10 \mu \mathrm{l}$ of $0.4 \%$ Trypan blue (Sigma Aldrich, T8154) and carefully mixed. A volume of $10 \mu \mathrm{l}$ was transferred to a chamber slide which was then inserted into an automated cell counter (Countess Automated Cell Counter) which visually depicts the cells and then electronically determined the percentage of viable cells.

\section{Proliferation}

ATP is the specialised carrier of energy within a cell. The quantification of ATP indicates the presence of metabolically active cells. The ATP luminescence assay was performed to assess cell proliferation using the CellTiter-Glo luminescent cell proliferation assay (Promega,

\begin{tabular}{|c|c|c|c|}
\hline \multicolumn{4}{|c|}{ Parameters } \\
\hline Laser type & $\begin{array}{c}\text { Semiconductor } \\
\text { (Diode) }\end{array}$ & & \\
\hline Wavelength $(\mathrm{nm})$ & 636 & 825 & 1060 \\
\hline Wave emission & Continuous & Continuous & Continuous \\
\hline Power output (mW) & \pm 85 & \pm 85 & \pm 85 \\
\hline Power density $\left(\mathrm{mW} / \mathrm{cm}^{2}\right)$ & 9.36 & 9.36 & 9.36 \\
\hline Spot size $\left(\mathrm{cm}^{2}\right)$ & 9.1 & 9.1 & 9.1 \\
\hline $\begin{array}{c}\text { Fluence }\left(\mathrm{J} / \mathrm{cm}^{2}\right) \\
\text { Duration of irradiation } \pm \\
\operatorname{min~sec}\end{array}$ & $\begin{array}{c}5,10,20 \text { and } 40 \\
8 \mathrm{~min} 54 \mathrm{sec} \\
17 \mathrm{~min} 48 \mathrm{sec} \\
35 \mathrm{~min} 36 \mathrm{sec} \\
\text { and } \\
71 \mathrm{~min} 13 \mathrm{sec}\end{array}$ & $\begin{array}{c}5,10,20 \text { and } 40 \\
8 \mathrm{~min} 54 \mathrm{sec} \\
17 \mathrm{~min} 48 \mathrm{sec} \\
35 \mathrm{~min} 36 \mathrm{sec} \\
\text { and } \\
71 \mathrm{~min} 13 \mathrm{sec}\end{array}$ & $\begin{array}{c}5,10,20 \text { and } 40 \\
8 \mathrm{~min} 54 \mathrm{sec} \\
17 \mathrm{~min} 48 \mathrm{sec} \\
35 \mathrm{~min} 36 \mathrm{sec} \\
\text { and } 71 \mathrm{~min} 13 \\
\mathrm{sec}\end{array}$ \\
\hline
\end{tabular}

Table 1: Laser parameters using the 636,825 and $1060 \mathrm{~nm}$ diode lasers.
G7570). The ATP assay exploits the properties of luciferase to generate a sensitive stable luminescent signal and prevents endogenous ATP released during cell lysis.

Fifty microliters of ATP CellTiter-Glo reagent was added to an equivalent volume of cell suspension in an opaque-walled 96 well plate (BD Biosciences, 353296). The plate was mixed on an orbital shaker at $250 \mathrm{rpm}$ (Heidolph Polymax Orbital, Labotec, 1040) for 2 min to induce lysis and incubated for $10 \mathrm{~min}$ at room temperature in the dark. The application led to the production of a luminescent signal that was measured using a Multilabel Counter (Perkin Elmer, VICTOR3 ${ }^{\mathrm{m}}$, 1420) in RLU. For a background control, $50 \mu \mathrm{l}$ of media was included into a well containing no cells. The RLU value obtained from the background control well was deducted from all the RLU values from the wells containing samples.

\section{Cytotoxicity}

Cytotoxicity was assessed by measuring the amount of $\mathrm{LDH}$ released from the cytosol due to membrane damage. This oxidoreductase interconverts lactate into pyruvate. Its discharge from the cytosol leads to an unusual increase of the enzyme in the bloodstream in vivo or culture media in vitro. In the nonradioactive colorimetric assay, LDH reacted to convert a tetrazolium salt (in the reconstituted reagent, oxidised form) into a quantifiable red formazan product (reduced form) in a $\mathrm{NADH}$ dependent reaction. The product of this enzymatic reaction is proportional to the number of cells that have been lysed or damaged.

Cytotoxicity was evaluated using the CytoTox $96^{\circ}$ nonradioactive cytotoxicity assay (Promega, G400). Fifty microliters of reconstituted reagent was added to an equal volume of culture media in a 96 well plate and incubated in the dark at room temperature for $30 \mathrm{~min}$. The colorimetric compound was measured spectrophotometrically at 490 nm using a multilabel Counter (Perkin Elmer, VICTOR ${ }^{\text {rm }}, 1420$ ).

\section{Statistics}

Results were accumulated and processed using Sigma plot version 12. All assays were repeated at least four times. All error bars represent standard error of the mean (SEM) $(n=4)$. For statistical evaluation, Student's paired t-test was used, and significance was defined as $\mathrm{p}<0.05\left(^{*}\right), \mathrm{p}<0.01\left(^{(*}\right)$ or $\left.\mathrm{p}<0.001{ }^{(* *}\right)$. For fluorescence emission intensity analysis, a background subtraction was performed for all of the data.

\section{Results}

\section{Protein detection of CD133}

Positive identification of CD133 isolated CSCs was performed using flow cytometric antibody identification. Secondary antibody immunofluorescent labelling technique was used to label the CD133 antigen on the isolated CSCs. Where the secondary antibody was FITC bound. Expression of the marker was seen on the isolated lung CSCs, as well as the positive control cell line $\mathrm{CaCo}_{2}$. No fluorescence was observed from the negative control cell line SKUT-1. Positive expression of the CD133 antigenic surface marker indicated positive isolation of lung CSCs. The majority of the cell population was identified as CSCs. Results indicated that the cells isolated had been characterised as CD133 positive shown in Figure 1 [33].

\section{Viability}

The percentage viability of cells post irradiation with LILI at 636 $\mathrm{nm}, 825 \mathrm{~nm}$ and $1060 \mathrm{~nm}$ with LF-LILI of 5, 10 and $20 \mathrm{~J} / \mathrm{cm}^{2}$ and HFLILI of $40 \mathrm{~J} / \mathrm{cm}^{2}$ is demonstrated in Tables $2-4$. 
Citation: Crous A, Abrahamse H (2016) High Fluence Low Intensity Laser Irradiation Bioinhibits Viability and Proliferation of Lung Cancer Stem Cells. J Stem Cell Res Ther 6: 368. doi: 10.4172/2157-7633.1000368

Page 4 of 8

The percentage of viable cells post irradiation did not show any significant increase in viability when using fluences of $5-20 \mathrm{~J} / \mathrm{cm}^{2}$. Although a significant decrease in viability was seen when using HFLILI of $40 \mathrm{~J} / \mathrm{cm}^{2}$ at $48 \mathrm{~h}$ and $72 \mathrm{~h}$. This indicated membrane damage of those cells irradiated leading to a decrease in percentage viability (Table 2).

LILI using a wavelength of $825 \mathrm{~nm}$ had significant changes on percentage viability of isolated lung CSCs. Statistical significances were observed for $10 \mathrm{~J} / \mathrm{cm}^{2}$ at $24 \mathrm{~h}(\mathrm{p}<0.05), 48 \mathrm{~h}(\mathrm{p}<0.01)$ and $72 \mathrm{~h}(\mathrm{p}<0.01)$. Indicating that LILI have an increasing effect on viability leading to enhanced membrane integrity. A significant decrease was seen for 40 $\mathrm{J} / \mathrm{cm}^{2}$ for the incubation periods of $24 \mathrm{~h}$ and $48 \mathrm{~h}(\mathrm{p}<0.001)$. At $72 \mathrm{~h}$ a significant decrease in viability of $\mathrm{p}<0.01$ was seen. HF-LILI had severely decreased viability, indicating diminished membrane integrity (Table 3).

Irradiation of isolated lung CSCs at $1060 \mathrm{~nm}$ did not produce any significant effect on viability of the cells. A significant decrease was observed when using HF-LILI of $40 \mathrm{~J} / \mathrm{cm}^{2}$ at $24 \mathrm{~h}$ post irradiation. After $48 \mathrm{~h}$ and $72 \mathrm{~h}$ percentage viability was similar to their controls (Table 4 ).

\section{Proliferation}

Cell proliferation can be measured according to the ATP levels present over a period of time. As metabolically active cells produce
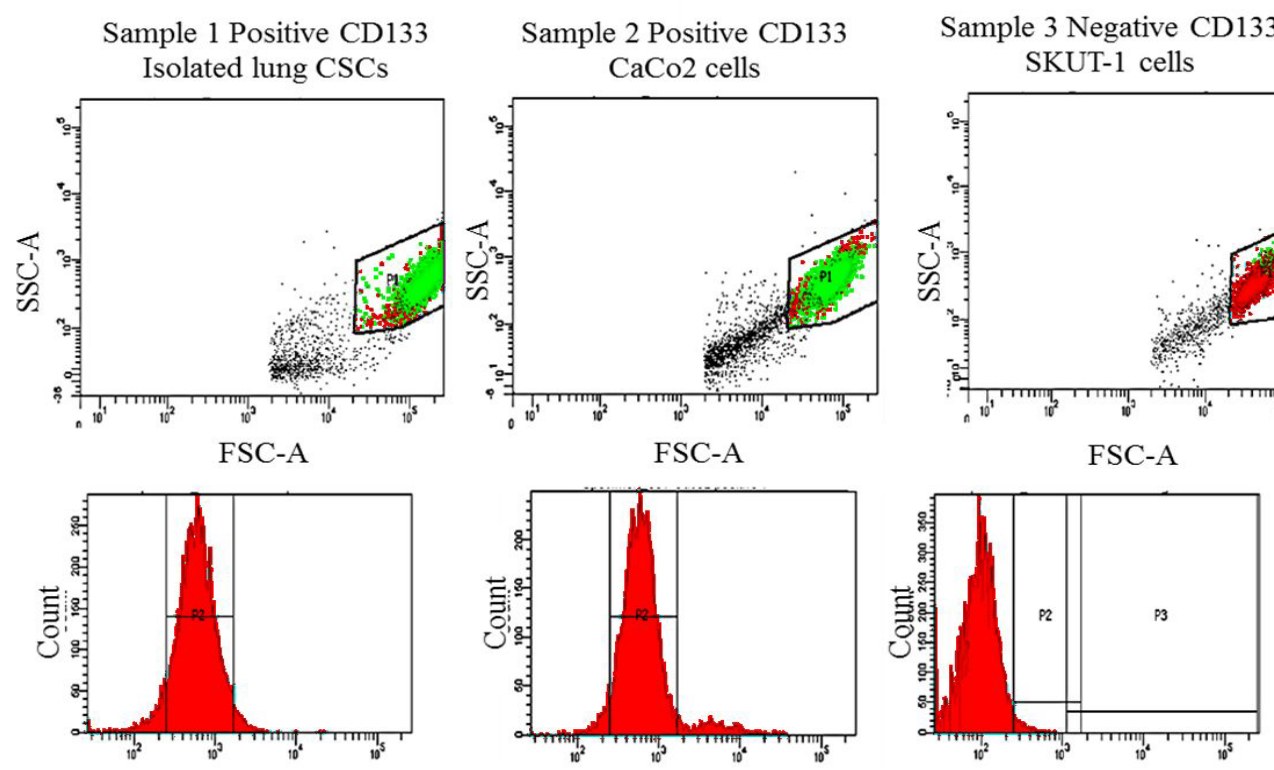

FITC
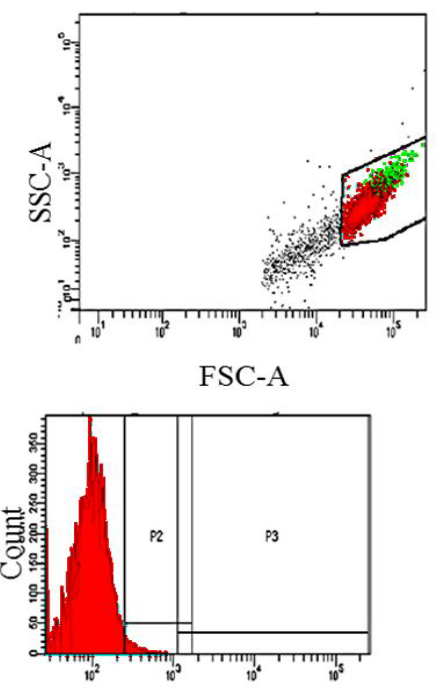

FITC

Figure 1: Identification of CD133 positive cells. Sample 1 and 2 are isolated lung CSCs and CaCo2 positive control which have been labelled with CD133 indicating positive gating for CD133 identification. Sample 3 which is SKUT-1 the negative control shows gating outside the population indicative of negative identification of the marker CD133 [33].

\begin{tabular}{|c|c|c|c|c|c|c|c|c|c|}
\hline \multirow{4}{*}{$24 \mathrm{~h}$} & \multicolumn{9}{|c|}{$636 \mathrm{~nm}$} \\
\hline & \multirow[b]{2}{*}{ Control } & \multicolumn{2}{|c|}{$5 \mathrm{~J} / \mathrm{cm}^{2}$} & \multicolumn{2}{|c|}{$10 \mathrm{~J} / \mathrm{cm}^{2}$} & \multicolumn{2}{|c|}{$20 \mathrm{~J} / \mathrm{cm}^{2}$} & \multicolumn{2}{|c|}{$40 \mathrm{~J} / \mathrm{cm}^{2}$} \\
\hline & & 89.25 & \pm 1.65 & 86.25 & \pm 1.88 & 83 & \pm 2.12 & 84.25 & \pm 1.93 \\
\hline & Test & 87.5 & \pm 2.02 & 90.75 & \pm 2.28 & 83 & \pm 2.67 & 78.75 & \pm 2.09 \\
\hline \multirow{2}{*}{$48 \mathrm{~h}$} & Control & 87.75 & \pm 0.85 & 83.75 & \pm 2.86 & 86 & \pm 2.27 & 89 & \pm 1.41 \\
\hline & Test & 89.5 & \pm 1.32 & 88.75 & \pm 2.86 & 87.75 & \pm 2.28 & 83.5 & ${ }^{*} \pm 1.32$ \\
\hline \multirow{2}{*}{$72 \mathrm{~h}$} & Control & 88.25 & \pm 1.37 & 87 & \pm 1.47 & 88.5 & \pm 1.55 & 89 & \pm 1.68 \\
\hline & Test & 88.5 & \pm 1.93 & 92 & \pm 1.47 & 89.25 & \pm 1.10 & 82 & ${ }^{* *} \pm 1.47$ \\
\hline
\end{tabular}

$p<0.05\left({ }^{*}\right), p<0.01\left(^{* *}\right)$

Table 2: Percentage Trypan Blue viability of isolated CD133 lung CSCs measured at $636 \mathrm{~nm}$.

\begin{tabular}{|c|c|c|c|c|c|c|c|c|c|}
\hline \multicolumn{10}{|c|}{$825 \mathrm{~nm}$} \\
\hline & & \multicolumn{2}{|c|}{$5 \mathrm{~J} / \mathrm{cm}^{2}$} & \multicolumn{2}{|c|}{$10 \mathrm{~J} / \mathrm{cm}^{2}$} & \multicolumn{2}{|c|}{$20 \mathrm{~J} / \mathrm{cm}^{2}$} & \multicolumn{2}{|c|}{$40 \mathrm{~J} / \mathrm{cm}^{2}$} \\
\hline \multirow{2}{*}{$24 \mathrm{~h}$} & Control & 86.25 & \pm 1.88 & 83.00 & \pm 2.12 & 89.00 & \pm 1.68 & 87.75 & \pm 0.85 \\
\hline & Test & 88.25 & \pm 1.88 & 93.00 & ${ }^{*} \pm 2.12$ & 87.75 & \pm 2.13 & 77.75 & $* * * \pm 0.85$ \\
\hline \multirow{2}{*}{$48 \mathrm{~h}$} & Control & 86.00 & \pm 2.27 & 89.00 & \pm 1.41 & 78.75 & \pm 2.09 & 88.25 & \pm 1.37 \\
\hline & Test & 88.00 & \pm 2.27 & 96.50 & ${ }^{* *} \pm 1.25$ & 83.25 & \pm 2.28 & 78.25 & $* * * \pm 1.18$ \\
\hline \multirow{2}{*}{$72 \mathrm{~h}$} & Control & 84.25 & \pm 1.93 & 87.00 & \pm 1.47 & 82.00 & \pm 1.47 & 86.25 & \pm 1.88 \\
\hline & Test & 86.25 & \pm 1.93 & 96.75 & ${ }^{* *} \pm 1.31$ & 80.75 & \pm 2.05 & 74.00 & ${ }^{* *} \pm 2.16$ \\
\hline
\end{tabular}

$\mathrm{p}<0.05\left(^{*}\right), \mathrm{p}<0.01\left(^{* *}\right)$ or $\mathrm{p}<0.001\left(^{* * *}\right)$

Table 3: Percentage Trypan Blue viability of isolated CD133 lung CSCs measured at $825 \mathrm{~nm}$. 
Citation: Crous A, Abrahamse H (2016) High Fluence Low Intensity Laser Irradiation Bioinhibits Viability and Proliferation of Lung Cancer Stem Cells. J Stem Cell Res Ther 6: 368. doi: 10.4172/2157-7633.1000368

Page 5 of 8

\begin{tabular}{|c|c|c|c|c|c|c|c|c|c|}
\hline \multicolumn{10}{|c|}{$1060 \mathrm{~nm}$} \\
\hline \multicolumn{4}{|c|}{$5 \mathrm{~J} / \mathrm{cm}^{2}$} & \multicolumn{2}{|c|}{$10 \mathrm{~J} / \mathrm{cm}^{2}$} & \multicolumn{2}{|c|}{$20 \mathrm{~J} / \mathrm{cm}^{2}$} & \multicolumn{2}{|c|}{$40 \mathrm{~J} / \mathrm{cm}^{2}$} \\
\hline \multirow{2}{*}{$24 \mathrm{~h}$} & Control & 89.00 & \pm 1.68 & 84.25 & \pm 1.93 & 83.00 & \pm 2.12 & 87.75 & \pm 0.85 \\
\hline & Test & 88.50 & \pm 0.64 & 87.75 & \pm 1.88 & 85.00 & \pm 1.58 & 84.75 & ${ }^{*} \pm 1 \pm 0.85$ \\
\hline \multirow{2}{*}{$48 \mathrm{~h}$} & Control & 82.00 & \pm 1.47 & 86.00 & \pm 2.27 & 78.25 & \pm 1.18 & 88.25 & \pm 1.37 \\
\hline & Test & 85.00 & \pm 0.85 & 89.00 & \pm 2.27 & 77.75 & \pm 1.49 & 84.25 & \pm 1.93 \\
\hline \multirow{2}{*}{$72 \mathrm{~h}$} & Control & 87.00 & \pm 1.47 & 86.25 & \pm 1.88 & 86.25 & \pm 1.88 & 82.00 & \pm 1.47 \\
\hline & Test & 89.00 & \pm 1.58 & 89.25 & \pm 1.88 & 84.50 & \pm 1.84 & 78.00 & \pm 1.22 \\
\hline
\end{tabular}

Table 4: Percentage Trypan Blue viability of isolated CD133 lung CSCs measured at $1060 \mathrm{~nm}$

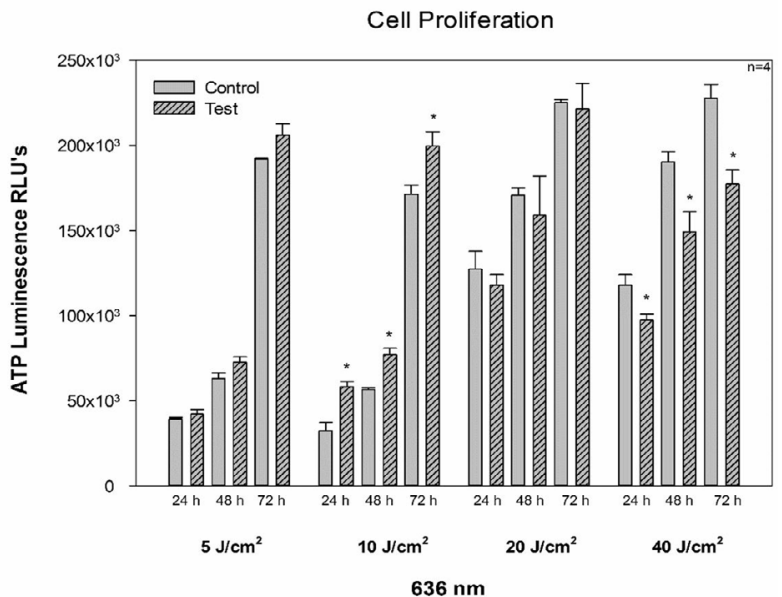

Figure 2: ATP proliferation of isolated CD133 lung CSCs measured at $636 \mathrm{~nm}$. All irradiated test samples were compared to their respective controls. Test samples received irradiation at fluence of $5-40 \mathrm{~J} / \mathrm{cm}^{2}$. Statistical significances were observed at $10 \mathrm{~J} / \mathrm{cm}^{2}$ having an increase in proliferation with a p-value of $<0.05\left(^{*}\right)$. A significant decrease in proliferation was observed at $40 \mathrm{~J} / \mathrm{cm}^{2}$ indicating $\mathrm{p}<0.05\left(^{*}\right)$. The changes observed at $5 \mathrm{~J} / \mathrm{cm}^{2}$ and $20 \mathrm{~J} / \mathrm{cm}^{2}$ weren't significant $\left(p<0.05\left(^{*}\right), p<0.01\left(^{* *}\right)\right.$ or $\left.p<0.001\left(^{* * *}\right)\right)$.

greater amounts of ATP than cells which are starting to die. These levels can be measured at several time intervals to produce a growth trend of viable cells. ATP will induce proliferation in cells which is directly proportional to the cells metabolic rate controlled by the mitochondrion. Results are indicated as follows (Figures 2-4). All samples indicated an increase in proliferation as time elapse from $24 \mathrm{~h}$ to $72 \mathrm{~h}$. This was due to metabolically active cells aiding in the proliferation rate.

Irradiation at $636 \mathrm{~nm}$ produced a definitive rise in cellular proliferation, which increased after each incubation period of $24 \mathrm{~h}$. Significant changes were seen at $10 \mathrm{~J} / \mathrm{cm}^{2}$ where test samples compared to their controls had a significant stimulation in mitochondrial activity leading to increased levels of ATP $(p<0.05)$. This change was observed for all three incubation periods. Although a significant decrease was observed for $40 \mathrm{~J} / \mathrm{cm}^{2}(\mathrm{p}<0.05)$, where irradiation induced a decrease in metabolic activity using a high fluence of LILI.

Results indicated that irradiating isolated lung CSCs at $825 \mathrm{~nm}$ had the most significant effects on the cellular metabolic rate, as most fluences presented with a significant change in ATP levels. An increase in proliferation was observed at $5 \mathrm{~J} / \mathrm{cm}^{2}$ after three incubation periods of 24 hours each. A significance was seen at $48 \mathrm{~h}(\mathrm{p}<0.05)$. Evaluation of test samples post irradiation of $10 \mathrm{~J} / \mathrm{cm}^{2}$ showed significant changes with a $\mathrm{p}$ value of $<0.01$ for all incubation periods, having more significant effects than $636 \mathrm{~nm}$ and $1060 \mathrm{~nm}$. Irradiation at $20 \mathrm{~J} / \mathrm{cm}^{2} \mathrm{did}$ not produce significant changes when comparing tests to their controls,
Cell Proliferation

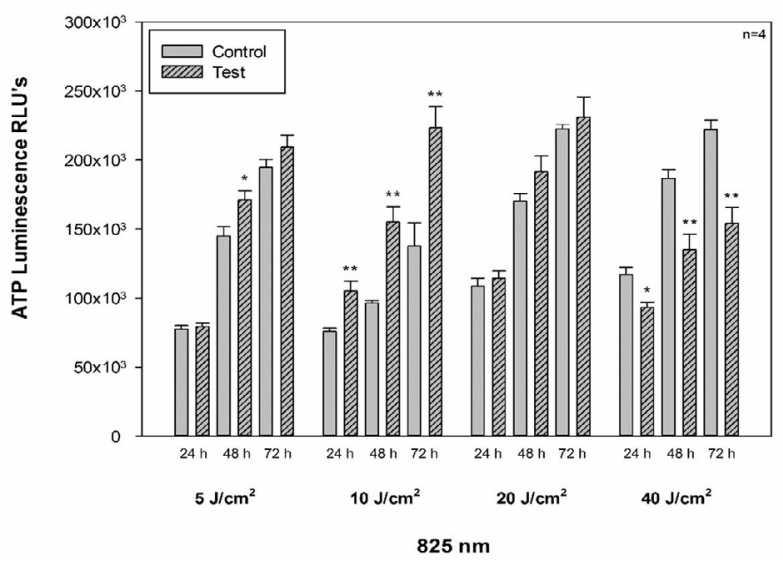

Figure 3: ATP proliferation of isolated CD133 lung CSCs measured at 825 $\mathrm{nm}$. All irradiated test samples were compared to their respective controls. Test samples received irradiation at a fluence of $5-40 \mathrm{~J} / \mathrm{cm}^{2}$. Statistical significances were observed at $10 \mathrm{~J} / \mathrm{cm}^{2}$ having an increase in proliferation with a $p$ value of $\left.<0.01{ }^{(*}\right)$. A significant decrease in proliferation was observed at $40 \mathrm{~J} / \mathrm{cm}^{2}$ indicating $\left.p<0.01{ }^{* *}\right)$. A significant difference was observed for $5 \mathrm{~J} / \mathrm{cm}^{2}, p<0.05$ at $48 \mathrm{~h}$. Other changes observed at $5 \mathrm{~J} / \mathrm{cm}^{2}$ and $20 \mathrm{~J} / \mathrm{cm}^{2}$ did not show any significance $\left(p<0.05\left(^{*}\right), p<0.01\left(^{* *}\right)\right.$ or $p<0.001\left(^{* * *}\right)$ ).

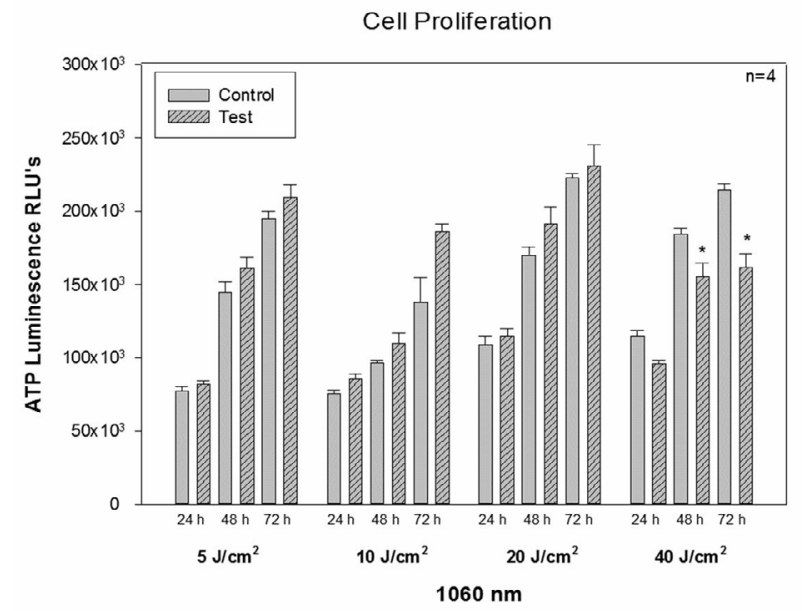

Figure 4: ATP proliferation of isolated CD133 lung CSCs measured at 1060 $\mathrm{nm}$ and $5,10,20$ and $40 \mathrm{~J} / \mathrm{cm}^{2}$. A significant decrease in proliferation was observed at $40 \mathrm{~J} / \mathrm{cm}^{2}$ after 48 and $72 \mathrm{~h}$ indicating $p<0.05\left(^{* *}\right) .\left(p<0.05\left(^{*}\right)\right.$, $\left.p<0.011^{(* *}\right)$ or $\left.p<0.001{ }^{* * *}\right)$ ).

although a similar trend in proliferation was observed over time. There was a definitive decrease in ATP levels observed post LILI of $40 \mathrm{~J} / \mathrm{cm}^{2}$. Where after $24 \mathrm{~h}$ a significant decrease of $\mathrm{p}<0.05$ was seen and at 48 - 
Citation: Crous A, Abrahamse H (2016) High Fluence Low Intensity Laser Irradiation Bioinhibits Viability and Proliferation of Lung Cancer Stem Cells. J Stem Cell Res Ther 6: 368. doi: 10.4172/2157-7633.1000368

Page 6 of 8

$72 \mathrm{~h}$ a decrease of $\mathrm{p}<0.01$ were observed at both incubation periods. This significant decrease showed to be greater than that of $636 \mathrm{~nm}$ and $1060 \mathrm{~nm}$.

\section{Cytotoxicity}

The level of $\mathrm{LDH}$ released was assessed using the CytoTox96 nonradioactive cytotoxicity assay which measured the amount of LDH that was released into the culture media. This measurement describes the degree of cell damage related to membrane damage of the isolated lung CSCs. LDH that was released from the cytosol was quantified by absorbance measurement. Treated cells when compared to their controls released notable although statistically insignificant amounts of LDH in all wavelengths using fluences of $5-20 \mathrm{~J} / \mathrm{cm}^{2}$ having similar absorbance values. An increase in cell damage was observed with treatment of 40 $\mathrm{J} / \mathrm{cm}^{2}$ at wavelengths $636 \mathrm{~nm}, 825 \mathrm{~nm}$ and $1060 \mathrm{~nm}$ when compared to the controls and other fluences which was significant having a $p$ value of $<0.05$ (Tables 5-7).

\section{Discussion}

In this study we explored the possible outcomes of LILI on lung CSCs. Promonin 1 (CD133) a pentaspan transmembrane glycoprotein, which is an antigenic structure usually found on stem cell surfaces [34] was used in this study for positive identification and isolation of CD133 lung CSCs. Positive isolation of CSCs was achieved using antigenic marker CD133, which was confirmed by previous studies stating that CSCs can be identified and isolated using their antigenic markers [35] and that CD133 have previously been used to identify and isolate different SCs and CSCs [36]. Antigenic identification of the surface marker CD133 was performed using control cell lines. The positive control cell line was $\mathrm{CaCo}_{2}$, which is a colorectal carcinoma cell line positive for the antigen CD133 [36] and negative control cell line SKUT-1 human uterus leiomyosarcoma, which do not express the surface marker. Results deduced from viability and proliferation assays show either a biostimulatory or bioinhibitory effect on the isolated CSCs depending on the wavelength and fluence used. The biostimulatory

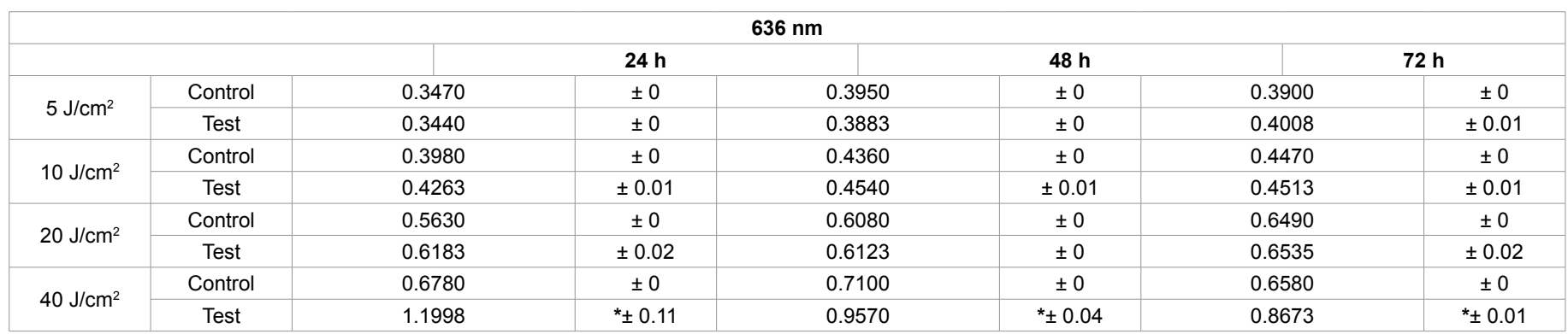

$\mathrm{p}<0.05\left(^{*}\right)$

Table 5: LDH cytotoxicity of isolated CD133 lung CSCs measured at $636 \mathrm{~nm}$. Test samples received irradiation of $5-40 \mathrm{~J} / \mathrm{cm}^{2}$. There was only a significant amount of toxicity observed when comparing test samples to their controls at $40 \mathrm{~J} / \mathrm{cm}^{2}\left(p<0.05^{*}\right)$. Other comparisons did not yield any significant LDH cytotoxicity.

\begin{tabular}{|c|c|c|c|c|c|c|c|}
\hline \multicolumn{8}{|c|}{$825 \mathrm{~nm}$} \\
\hline \multicolumn{5}{|c|}{$24 \mathrm{~h}$} & \multicolumn{2}{|l|}{$48 \mathrm{~h}$} & $72 \mathrm{~h}$ \\
\hline \multirow{2}{*}{$5 \mathrm{~J} / \mathrm{cm}^{2}$} & Control & 0.3070 & \pm 0 & 0.3520 & \pm 0 & 0.4020 & \pm 0 \\
\hline & Test & 0.3563 & \pm 0.02 & 0.3675 & \pm 0.01 & 0.4363 & \pm 0.02 \\
\hline \multirow{2}{*}{$10 \mathrm{~J} / \mathrm{cm}^{2}$} & Control & 0.4210 & \pm 0 & 0.4330 & \pm 0 & 0.4410 & \pm 0 \\
\hline & Test & 0.4265 & \pm 0.01 & 0.4258 & \pm 0.01 & 0.4398 & \pm 0 \\
\hline \multirow{2}{*}{$20 \mathrm{~J} / \mathrm{cm}^{2}$} & Control & 0.5950 & \pm 0 & 0.6000 & \pm 0 & 0.6310 & \pm 0 \\
\hline & Test & 0.6293 & \pm 0.01 & 0.6413 & \pm 0.01 & 0.6473 & \pm 0.01 \\
\hline \multirow{2}{*}{$40 \mathrm{~J} / \mathrm{cm}^{2}$} & Control & 0.6910 & \pm 0 & 0.6720 & \pm 0 & 0.7020 & \pm 0 \\
\hline & Test & 1.3306 & ${ }^{*} \pm 0.07$ & 1.0738 & ${ }^{*} \pm 0.06$ & 1.0405 & ${ }^{*} \pm 0.01$ \\
\hline
\end{tabular}

p $<0.05(*)$

Table 6: LDH cytotoxicity of isolated CD133 lung CSCs measured at $825 \mathrm{~nm}$. Test samples received irradiation of $5-40 \mathrm{~J} / \mathrm{cm}^{2}$. When comparing test samples to their nonirradiated controls only $40 \mathrm{~J} / \mathrm{cm}^{2}$ showed significant $\mathrm{LDH}$ release $\left(p<0.05^{*}\right)$. Other comparisons did not yield any significant LDH cytotoxicity.

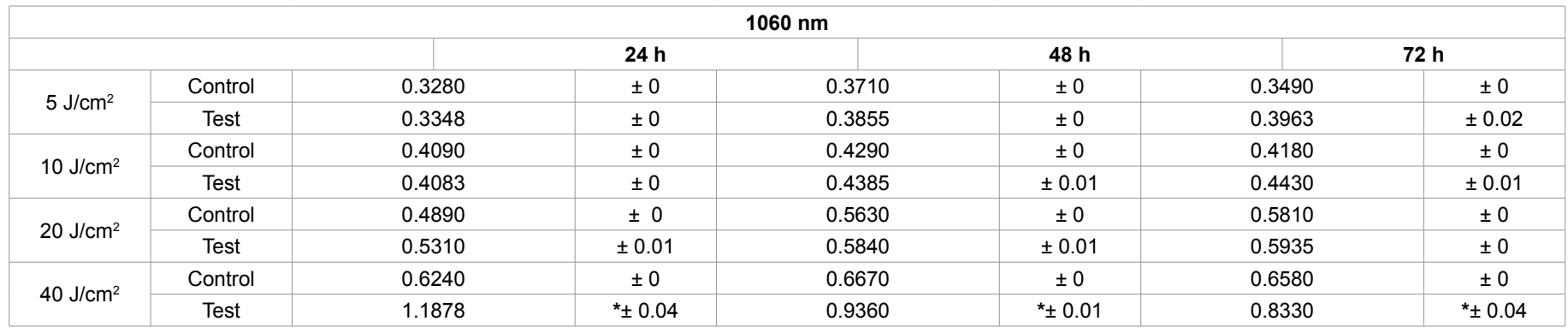

p<0.05(*)

Table 7: LDH cytotoxicity of isolated CD133 lung CSCs measured at $1060 \mathrm{~nm}$. Irradiation fluence ranged from $5-40 \mathrm{~J} / \mathrm{cm}^{2}$. Controls received no irradiation. When comparing tests to their respective controls only $40 \mathrm{~J} / \mathrm{cm}^{2}$ indicated a significant amount of cytotoxicity $\left(\mathrm{p}<0.05^{*}\right)$. Changes seen in other fluences did not have a significant amount of LDH leakage. 
Citation: Crous A, Abrahamse H (2016) High Fluence Low Intensity Laser Irradiation Bioinhibits Viability and Proliferation of Lung Cancer Stem Cells. J Stem Cell Res Ther 6: 368. doi: 10.4172/2157-7633.1000368

Page 7 of 8

effect which had the greatest statistical significance was seen when using LF-LILI of $10 \mathrm{~J} / \mathrm{cm}^{2}$ and a wavelength of $825 \mathrm{~nm}$. Other stimulatory effects were seen when irradiating cells with a wavelength of $636-825$ $\mathrm{nm}$ and fluence of $5-10 \mathrm{~J} / \mathrm{cm}^{2}$ concurring with previous research who have found similar results $[23,27,28]$. CSC self-renewal capabilities help them oppose cell death and damage [6]. This phenomenon was seen during treatment of CSCs with an increased energy level of $20 \mathrm{~J} / \mathrm{cm}^{2}$, as compared to non-cancerous cell lines which have died during exposure to increased energy levels [27]. These findings suggest a biostimulatory effect can be achieved on CSCs using irradiation between 5 and $20 \mathrm{~J} / \mathrm{cm}^{2}$ with wavelengths ranging from $636 \mathrm{~nm}-1060 \mathrm{~nm}$. Bioinhibition, having great statistical significance, was seen when irradiating samples with HF-LILI at $40 \mathrm{~J} / \mathrm{cm}^{2}$ when analysing viability and proliferation results. The above findings show that parameters such as wavelength, fluence and intensity play an important role in photobiomodulation of cellular metabolism [24,26-28]. There was little to no significance seen on isolated CSCs when treated with a wavelength of $1060 \mathrm{~nm}$ and fluence of $5-20 \mathrm{~J} / \mathrm{cm}^{2}$ having no metabolic effect on the cells. These results reveal that CSC photobiostimulation is only achieved using visible red light with wavelengths ranging between 636 and $825 \mathrm{~nm}$. Infra-red light $(1060 \mathrm{~nm})$ has little to no effect on CSC metabolism using LF-LILI. Cytotoxicity analysis revealed cells treated with LF-LILI $\left(5-20 \mathrm{~J} / \mathrm{cm}^{2}\right)$ using all respective wavelengths did not show any membrane damage as no significant amounts of LDH were released. High levels of LDH were seen when treating samples with HF-LILI of $40 \mathrm{~J} / \mathrm{cm}^{2}$ indicating significant membrane damage to the cells. Membrane damage can be directly related to cell death.

The hypothesis stating that CSCs contribute to cancer initiation, metastasis and relapse [37] raises concern not only when considering the development of cancer treatments but to the use of LILI as a photobiomodulative therapy. Modern day cancer therapies have restricted prognostic outcomes, lacking in its ability to kill CSCs along with the bulk of the tumour and produce adverse side effects. Research need to explore alternate therapies that include CSCs and their characteristics when developing treatments. When using LILI as a therapeutic model, one should take caution and consider the CSC characteristics, explicitly when applying LILI for its desired effects of increased cell proliferation and viability, [23] which poses to be harmful when considering treatment when CSCs are involved.

It shows to be apparent when developing cancer therapies that CSC death would be a promising approach and that focus need to be shifted towards achieving tumour cell specificity and exploiting cell death mechanisms whereby not only differentiated cancer cells but CSCs are also killed [38]. Obtaining statistical evidence pertaining the mechanism behind CSC cell death through induction of HFLILI would be required for the clinical application of low-power laser therapies. Since lung cancer consists of a heterogenic cell population including lung CSCs, multiple signalling pathways have to be studied and targeted for effective therapeutic benefit [39].

It has been shown that LILI can deliver apoptotic stimulatory triggers in cancer and CSCs [33,38]. Previous studies conducted on A549 lung cancer using LILI indicated no significant changes in cellular viability, proliferation and cytotoxicity when using a wavelength of $636 \mathrm{~nm}$. Indicating no significant effect without addition of a photosensitiser [40]. Photodynamic therapy, a cancer treatment that uses a photosensitive chemical which is activated by laser light, have been seen to induce membrane damage and apoptosis leading to cell death in lung cancer. The effectiveness of this treatment should be elaborated on by conducting experiments on lung CSCs, identifying its cell death mechanisms and whether there is a difference in cancer and CSC death.

\section{Acknowledgements}

This work was conducted at the Laser Research Centre at the University of Johannesburg and was supported by the National Laser Centre of South Africa.

\section{Conflict of Interest}

The authors indicate no potential conflict of interest.

\section{References}

1. Hanahan D, RA Weinberg (2000) The hallmarks of cancer. Cell 100: 57-70. [PubMed]

2. Goldthwaite CA (2006) Are stem cells involved in cancer?

3. Tsao AS (2013) Lung carcinoma.

4. Herbst RS, JV Heymach, SM Lippman (2008) Molecular Origins of Cancer Lung Cancer. N Engl J Med 359: 1367-1380.

5. Fidler IJ (1990) Critical factors in the biology of human cancer metastasis: twenty-eighth G.H.A. Clowes memorial award lecture. Cancer Res 50: 61306138. [PubMed]

6. Croker AK, AL Allan (2008) Cancer stem cells: implications for the progression and treatment of metastatic disease. J Cell Mol Med 12: 374-390. [PubMed]

7. Rahman M, Deleyrolle L, Vedam-Mai V, Azari H, Abd-El-Barr M, et al. (2011) The Cancer Stem Cell Hypothesis: Failures and Pitfalls. Neurosurgery 68: 531 545. [PubMed]

8. Garcion E, Naveilhan P, Berger F, Wion D (2009) Cancer stem cells: Beyond Koch's postulates. Cancer Lett 278: 3-8. [PubMed]

9. Tan BT, Park CY, Ailles LE, Weissman IL (2006) The cancer stem cell hypothesis: a work in progress. Lab Invest 86: 1203-1207. [PubMed]

10. Mohr M, Zänker KS, Dittmar T (2015) Cancer (stem) cell differentiation: An inherent or acquired property? Med Hypotheses 85: 1012-1018. [PubMed]

11. Kosovsky M (2012) Culture and Assay Systems Utilized for Cancer Stem Cell Research.

12. Magee JA, Piskounova E, Morrison SJ (2012) Cancer Stem Cells: Impact Heterogeneity, and Uncertainty. Cancer Cell 21: 283-296.

13. Pine SR, Marshall B, Varticovskia L (2008) Lung cancer stem cells. Dis Markers 24: 257-266. [PubMed]

14. Natarajan TG, FitzGerald KT (2007) Markers in normal and cancer stem cells Cancer Biomark 3: 211-231. [PubMed]

15. Caligur V (2008) The Cancer Stem Cell Hypothesis.

16. Levina V, Marrangoni AM, DeMarco R, Gorelik E, Lokshin AE (2008) Drugselected human lung cancer stem cells: cytokine network, tumorigenic and metastatic properties. PLoS One 3: e3077. [PubMed]

17. Chen YC, Hsu HS, Chen YW, Tsai TH, How CK, et al. (2008) Oct-4 expression maintained cancer stem-like properties in lung cancer-derived CD133-positive cells. PLoS One 3: e2637. [PubMed]

18. Bertolini G, Roz L, Perego P, Tortoreto M, Fontanella E, et al. (2009) Highly tumorigenic lung cancer CD133+ cells display stem-like features and are spared by cisplatin treatment. Proc Natl Acad Sci U S A 106: 16281-16286. [PubMed]

19. Yin AH, Miraglia S, Zanjani ED (1997) AC133, a novel marker for human hematopoietic stem and progenitor cells. Blood 90: 5002-5012. [PubMed]

20. Hamblin MR (2008) Mechanisms of low level light therapy.

21. Huang YY, Chen A, Hamblin M (2009) Low-Level Laser Therapy: an Emerging Clinical Paradigm. SPIE Newsroom.

22. Karu T (1989) Photobiology of Low-Power Laser Effects. Health Phys 56: 691 704. [PubMed]

23. de Villiers JA, Houreld NN, Abrahamse H (2011) Influence Of Low Intensity Laser Irradiation On Isolated Human Adipose Derived Stem Cells Over 72 Hours And Their Differentiation Potential Into Smooth Muscle Cells Using Retinoic Acid. Stem Cell Rev 7: 869-882. [PubMed] 
Citation: Crous A, Abrahamse H (2016) High Fluence Low Intensity Laser Irradiation Bioinhibits Viability and Proliferation of Lung Cancer Stem Cells. J Stem Cell Res Ther 6: 368. doi: 10.4172/2157-7633.1000368

24. Moore P, Ridgway TD, Higbee RG, Howard EW, Lucroy MD (2005) Effect of Wavelength on Low-Intensity Laser Irradiation-Stimulated Cell Proliferation In Vitro. Lasers Surg Med 36: 8-12. [PubMed]

25. Fonseca AS, Moreira TO, Paixão DL, Farias FM, Guimarães OR, et al. (2010) Effect of Laser Therapy on DNA Damage. Lasers in Surgery and Medicine 42 481-488. [PubMed]

26. Hu WP, Wang JJ, Yu CL, Lan CC, Chen GS, et al. (2007) Helium-Neon Laser Irradiation Stimulates Cell Proliferation Through Photostimulatory Effects In Mitochondria. J Invest Dermatol 127: 2048-2057. [PubMed]

27. Mvula B, Mathope T, Moore TJ, Abrahamse H (2008) The Effects of Low Level Laser Irradiation on Human Adipose Derived Stem Cells. Lasers Med Sci 23: 277-282. [PubMed]

28. Abrahamse H, Houreld NN, Muller S, Ndlovu L (2010) Fluence and Wavelength of Low Intensity Laser Irradiation Affect Activity and Proliferation of Human Adipose Derived Stem Cells. Medical Technology 24: 9-14.

29. Chow RT, David MA, Armati PJ (2007) 830 Nm Laser Irradiation Induces Varicosity Formation, Reduces Mitochondrial Membrane Potential and Blocks Fast Axonal Flow in Small and Medium Diameter Rat Dorsal Root Ganglion Neurons: Implications for the Analgesic Effects of $830 \mathrm{Nm}$ Laser. J Peripher Nerv Syst 12: 28-39. [PubMed]

30. Sun X, Wu S, Xing D (2010) The reactive oxygen species-Src-Stat3 pathway provokes negative feedback inhibition of apoptosis induced by high-fluence low-power laser irradiation. FEBS J 277: 4789-802. [PubMed]

31. Wang F, Chen TS, Xing D, Wang JJ, Wu YX (2005) Measuring dynamics of caspase- 3 activity in living cells using FRET technique during apoptosis induced by high fluence low-power laser irradiation. Lasers Surg Med 36: 2-7. [PubMed]
32. Wu S, Xing D, Gao X, Chen WR (2009) High fluence low-power laser irradiation induces mitochondrial per- meability transition mediated by reactive oxygen species. J Cell Physiol 218: 603-611. [PubMed]

33. Abrahamse $\mathrm{H}$, Crous A (2016) Biochemical responses of isolated lung cscs after application of low intensity laser irradiation. Proceedings of SPIE 9695 Mechanisms of Photobiomodulation Therapy XI, 96950J.

34. Salama R, Tang J, Gadgeel SM, Ahmad A, Sarkar FH (2012) Lung cancer stem cells: current progress and future perspectives. J Stem Cell Res Therap S7: 007.

35. Tirino V, Desideri V, Paino F, Papaccio G, De Rosa M (2012) Methods for cancer stem cell detection and isolation. Methods Mol Biol 879: 513-529. [PubMed]

36. Ren F, Sheng WQ, Du X (2013) CD133: A cancer stem cells marker, is used in colorectal cancers. World J Gastroenterol 19: 2603-2611. [PubMed]

37. Ferreira CG, Epping M, Kruyt FA, Giaccone G (2002) Apoptosis: target of cancer therapy. Clin Cancer Res 8: 2024-2034. [PubMed]

38. Sandeep S, Srikumar C (2014) Lung cancer stem cells: Molecular features and therapeutic targets. Mol Aspects Med 39: 50-60. [PubMed]

39. Manoto S, Abrahamse H (2011) Effect of a newly synthesized Zn sulfophthalocyanine derivative on cell morphology, viability, proliferation, and cytotoxicity in a human lung cancer cell line (A549). Lasers Med Sci 26: 523530. [PubMed]

40. Manoto SL, Sekhejane PR, Houreld NN, Abrahamse H (2012) Localization and phototoxic effect of Zinc Sulfophthalocyanine photosensitizer in human colon (DLD-1) and lung (A549) carcinoma cells (In Vitro). Photodiagnosis Photodyn Ther 9: 52-59. [PubMed] 